\title{
Characterizing the metabotype and its persistency in lactating Holstein cows: An approach toward metabolic efficiency measures
}

\author{
Michael Derno, ${ }^{1}$ Gerd Nürnberg, ${ }^{2}$ and Björn Kuhla ${ }^{1 *}$ \\ ${ }^{1}$ Institute of Nutritional Physiology "Oskar Kellner," Leibniz Institute for Farm Animal Biology (FBN), Wilhelm-Stahl-Allee 2, 18196 Dummerstorf, \\ Germany \\ ${ }^{2}$ Institute of Genetics and Biometry, Leibniz Institute for Farm Animal Biology (FBN), Wilhelm-Stahl-Allee 2, 18196 Dummerstorf, Germany
}

\section{ABSTRACT}

The variation in feed efficiency among dairy cows is due to differences in fermentation and digestion characteristics, but recent studies have suggested that various aspects of postabsorptive metabolic processes including heat production or the metabolizable energy for maintenance are more crucial. Thus, metabolic efficiency largely determines feed efficiency, but whether divergent feed efficient cows differ in $\mathrm{O}_{2}$ consumption and metabolic $\mathrm{CO}_{2}$ production, directly determining the metabolic rate has not been investigated. Therefore, the objective of the present study was to determine whether variation in ME intake (MEI), $\mathrm{O}_{2}$ consumption, and metabolic $\mathrm{CO}_{2}$ production account for the variation in metabolic efficiency of dairy cows and whether this effect persists across the lactation cycle. Eighteen cows with different German breeding value functional herd life were kept in freestalls with ad libitum access to a total mixed ration that was kept constant in composition throughout the first lactation. Cows were blood sampled and weighed at wk 5, 13, and 42 postpartum (pp) and transferred into respiration chambers. Animals were retrospectively clustered according to MEI, $\mathrm{O}_{2}$ consumption, and metabolic $\mathrm{CO}_{2}$ production, each normalized to metabolic body weight (mBW). Cluster analysis revealed 9 high metabolically efficient (high-Meff) and 9 low metabolically efficient cows. The high-Meff cows had greater MEI and feed conversion efficiency, produced less metabolic $\mathrm{CO}_{2}$ and methane, had a stronger negative energy balance, and tended to have a lower metabolic respiratory quotient. Further, high-Meff cows had lower residual MEI, less heat energy loss, and lower plasma glucose concentrations, but used a greater portion of body reserves instead of feed energy for milk synthesis, particularly at wk 5 and 13 pp. However, these group differences did not persist by wk $42 \mathrm{pp}$. Cow groups were not different

Received January 9, 2019.

Accepted April 1, 2019.

*Corresponding author: b.kuhla@fbn-dummerstorf.de in $\mathrm{O}_{2}$ consumption, milk yield, metabolizable energy for maintenance, or the efficiency of tissue utilization for milk synthesis, but high-Meff cows tended to have the lower German relative breeding value functional herd life, indicating a link between metabolic performance and productive lifespan. In conclusion, the use of a clustering approach involving $\mathrm{MEI} / \mathrm{mBW}, \mathrm{O}_{2} / \mathrm{mBW}$, and $\mathrm{CO}_{2} / \mathrm{mBW}$ seems to be a promising method to differentiate cows with divergent metabolic efficiency but does not allow identifying an individual metabotype that persists across the whole lactation cycle.

Key words: energy metabolism, metabolic efficiency, lactation, dairy cow

\section{INTRODUCTION}

The global demand for meat and dairy products continues to increase primarily because of an expanding world human population and increase in lifespan. On the other hand, the size of global farm land for the production of feed for animals decreases steadily (Salter, 2017) and feed costs amount to the largest proportion of overall costs at least in pasture-based systems of milk production (Hanrahan et al., 2018). Therefore, improving feed efficiency of dairy cows is still an urgent need, although it has increased substantially in the past decades (Capper et al., 2009).

Feed efficiency, in general, is the proportion of feed converted to products such as milk and meat. For dairy cows, feed conversion efficiency (FCE) is defined as the ratio of kilograms of milk per kilogram of DMI. Another measure of feed efficiency is residual feed intake (RFI), which was first defined as the difference between actual and predicted feed intake of beef cattle (Koch et al., 1963). Five major biological processes involving feed intake pattern, fermentation and digestion of feed, anabolic and catabolic postabsorptive metabolism, physical activity, and thermoregulation determine the level of feed efficiency of a healthy cow (Herd and Arthur, 2009). Partial contributions of each of these biological processes may vary between animals, but none of these processes has been included in the definition of FCE or 
RFI. However, some recent studies investigated different components of feed efficiency in divergent RFI cows. For example, dairy cows classified as being highly feed efficient (low RFI) differ in their rumen microbial community composition compared with less feed efficient (high RFI) counterparts (Jewell et al., 2015). Also, low RFI cows were characterized by a greater apparent $\mathrm{N}$ digestibility, by a trend for greater digestibility of DM and of OM, as well as by lesser excretion of feed $\mathrm{N}$ as fecal N (Rius et al., 2012). The greater digestibility in low RFI cows may not only depend on a more effective microbiome and digestive ability but also on diet composition. In a recent study it was demonstrated that digestive ability was not different between low and high RFI cows on a high starch diet but varied between 9 to $31 \%$ between animals on low starch diets (Potts et al., 2017). These authors speculated that differences in postabsorptive metabolic processes, heat production, or energy utilization for maintenance account more for the variation in RFI than digestibility (Potts et al., 2017). Approaches to directly measure metabolic heat production and energy utilization for maintenance require experiments in metabolic chambers. Only a few studies have been conducted on the comparison of maintenance energy requirements or heat production of mid- and late-lactating dairy cows with contrasting feed efficiencies (Arndt et al., 2015; Dong et al., 2015). High-FCE cows partitioned $15 \%$ more feed energy toward milk but also maintenance functions, secreted less portion of feed $\mathrm{N}$ through urine, and produced less heat than low FCE counterparts (Arndt et al., 2015). Thus, high FCE cows possess a greater metabolic efficiency (conversion of postabsorptive feed energy to milk) both during mid and late lactation (Arndt et al., 2015), suggesting that a persisting metabotype of an animal determines its feed efficiency to a large extent.

Within the first 5 wk of early lactation, dairy cows may use $46 \mathrm{~kg}$ of body fat and $12 \mathrm{~kg}$ of body protein for milk synthesis and maintenance (Komaragiri et al., 1998). Therefore, good estimates for feed efficiency of dairy cows need to account, besides feed energy intake and milk energy losses, also for body mass changes, stage of lactation, and parity (Hurley et al., 2016; Potts et al., 2017). Arndt et al. (2015), however, did not investigate whether the differences in the cow's feed efficiency and metabotype already existed in early lactation and whether the portion of tissue energy used for milk production differed between divergent FCE cows.

Feed efficient (low-RFI) beef cattle were characterized to have lower methane $\left(\mathrm{CH}_{4}\right)$ losses and lower metabolic rates; the latter is the amount of $\mathrm{ME}$ expended as heat per kilogram of metabolic body weight, as compared with less feed efficient counterparts (Nkrumah et al., 2006). The metabolic rate is directly related to the amount of $\mathrm{O}_{2}$ consumed and $\mathrm{CO}_{2}$ produced, and the level of total splanchnic tissue $\mathrm{O}_{2}$ consumption tended to be higher in steers with high-FCE (higher ADG per $\mathrm{kg}$ of DMI; Hersom et al., 2003). However, whether divergent $\mathrm{FCE}$ cows differ in $\mathrm{O}_{2}$ consumption and metabolic $\mathrm{CO}_{2}$ production in dependency of energy intake has not been investigated. Therefore, the objective of the present study was to determine whether variation in ME intake (MEI), $\mathrm{O}_{2}$ consumption, and metabolic $\mathrm{CO}_{2}$ production accounts for the variation in metabolic efficiency, and if so whether this effect persists through the course of lactation.

\section{MATERIALS AND METHODS}

\section{Animals and Experimental Design}

The experimental protocol was approved by the local animal ethics committee (Landesamt für Landwirtschaft, Lebensmittelsicherheit und Fischerei Mecklenburg-Vorpommern; approval no. 7221.1-1.-053/13). Eighteen German Holstein cows at first calving between October 2013 and January 2014 were used from the herd at the Leibniz-Institute for Farm Animal Biology, Dummerstorf, Germany. The herd included 18 animals with a high German relative breeding value functional herd life (mean \pm SE: $121 \pm 1$; range from 109-128) and 18 animals with a low German relative breeding value functional herd life (96 \pm 1 , range from 85-106). Breeding values were determined from genomic data (Masterrind, 2019). Animals used for the present study were randomly selected from the 2 genotype groups. Cows were kept in freestalls with ad libitum access to water and fed a TMR that was kept constant in composition throughout the first lactation. Diet composition was formulated according to recommendations of the German Society of Nutrition Physiology (GfE, 2004). Before calving, animals were halter-trained and well adapted to respiration chambers at least 3 times until the animal showed regular eating, drinking, ruminating behavior, and lying down.

\section{Sample Collection and Respiration Chamber Measurements}

At wk 5, 13, and $42(\mathrm{SE} \pm 0.2)$ postpartum (pp), cows were blood sampled directly before transfer to respiration chambers. Blood samples were collected from the left jugular vein in 9-mL monovettes containing EDTA (Sarstedt, Nümbrecht, Germany). Monovettes were immediately placed on ice and centrifuged at $1,570 \times g$ for $20 \mathrm{~min}$ at $4^{\circ} \mathrm{C}$ to obtain plasma which was stored at $-80^{\circ} \mathrm{C}$ before analysis. Plasma nonesterified fatty acids (NEFA), triglycerides, BHB, and glucose concentra- 
tions were analyzed photometrically (Abx Pentra 400, Horiba, Kyoto, Japan) using the following kits: NEFAHR(2) (Wako Chemicals, Neuss, Germany) for NEFA, \#A11A01640 (Abx-Horiba) for triglycerides, \#RB 1008 (Labor+Technik Lehmann, Berlin, Germany) for BHB, and \#A11A01667 (Axon Lab, Reichenbach, Germany) for glucose.

Cows were weighed to measure BW directly before and after respiration chamber measurement to calculate mean metabolic body weight $(\mathbf{m B W})$ :

$$
\mathrm{mBW}=\mathrm{BW}^{0.75}
$$

Within chambers, animals were kept in tiestall at $15^{\circ} \mathrm{C}$, with a dark-light cycle from 0600 to $1900 \mathrm{~h}$ and ad libitum access to water. A TMR sample was taken at each time of respiration chamber measurements for the analysis of DM and diet composition. Feed analyses were conducted by the Landwirtschaftliche Untersuchungs- und Forschungsanstalt (LUFA, Rostock, Germany). The chemical composition of the TMR is shown in Table 1. Based on the results obtained for CP, crude fiber $(\mathrm{CFi})$, and crude fat $(\mathrm{CFa}), \mathrm{ME}$ content of the diet was calculated according to Boguhn et al. (2003):

$$
\begin{gathered}
\mathrm{ME}(\mathrm{MJ} / \mathrm{kg} \text { of } \mathrm{DM})=6.0756+0.19123 \mathrm{CFa} \\
+0.02459 \mathrm{CP}-0.000038 \mathrm{CFi}^{2}-0.002139 \mathrm{CFa}^{2} \\
-0.000060 \mathrm{CP}^{2} .
\end{gathered}
$$

After an overnight stay allowing gas exchange equilibration, measurement of gas concentrations started at $0700 \mathrm{~h}$. On d 1 in the chamber, animals were fed at 0700 and $1630 \mathrm{~h}$ for ad libitum intake. The amount of feed consumed was determined every 6 min by feed disappearance from the trough placed on an electronic scale for $24 \mathrm{~h}$. From this, daily DMI and MEI were calculated. The residual metabolizable energy intake (RMEI) was calculated as the difference between the actual MEI and the theoretical MEI (MEI theo $)$ calculated from the BW, milk yield, and milk constituents using the software HERDEplus (dsp agrosoft GmbH, Paretz, Germany), which is based on the GfE (2004) equations.

At $0700 \mathrm{~h}$ on $\mathrm{d} 2$, feed residuals were removed and gas exchanges were measured for further $24 \mathrm{~h}$ (fasting period). The airflow through the chamber amounted to approximately $30 \mathrm{~m}^{3}$ per $\mathrm{h}$ and was measured by a differential-pressure type $\mathrm{V}$ cone flow meter (McCrometer, Hemet, $\mathrm{CA}$ ). Concentrations of $\mathrm{CO}_{2}$ and $\mathrm{CH}_{4}$ in the chamber were analyzed by infrared-absorption and the concentration of $\mathrm{O}_{2}$ was analyzed paramagnetically (SIDOR SICK AG, Waldkirch, Germany) every 6 min.
As total $\mathrm{CO}_{2}$ production $\left(\mathrm{V}_{\mathrm{CO} 2}\right)$ is the sum of fermentative $\left(\mathrm{CO}_{2}\right.$ ferm $)$ and metabolic $\mathrm{CO}_{2}\left(\mathrm{CO}_{2}\right.$ metab $), \mathrm{CO}_{2}$ ferm was estimated according to Chwalibog et al. (1996):

$$
\mathrm{V}_{\mathrm{CO} 2 \text { ferm }}(\mathrm{L})=1.7 \times \mathrm{V}_{\mathrm{CH} 4}(\mathrm{~L}),
$$

in which the factor 1.7 is constant for a variety of diet compositions. Accordingly, $\mathrm{V}_{\mathrm{CO} 2}$ metab was calculated by subtracting $\mathrm{V}_{\mathrm{CO} 2 \text { ferm }}$ from $\mathrm{V}_{\mathrm{CO} 2}$ and the metabolic respiratory quotient $\left(\mathbf{R Q}_{\text {metab }}\right)$ as $\mathrm{V}_{\mathrm{CO} 2 \text { metab }} / \mathrm{V}_{\mathrm{O} 2}$ (Derno et al., 2013). Energy expenditure (EE) was calculated according to the following equation (Brouwer, 1965):

$$
\begin{gathered}
\mathrm{EE}(\mathrm{kJ})=16.18 \mathrm{~V}_{\mathrm{O} 2}(\mathrm{~L})+5.02 \mathrm{~V}_{\mathrm{CO} 2}(\mathrm{~L}) \\
-2.17 \mathrm{~V}_{\mathrm{CH} 4}(\mathrm{~L})-5.99 \mathrm{~N}_{\mathrm{u}}(\mathrm{g}),
\end{gathered}
$$

where $\mathrm{N}_{\mathrm{u}}$ is urine $\mathrm{N}$ excretion. Physical-activity-related $\mathrm{EE}\left(\mathrm{EE}_{\mathrm{act}}\right)$ was calculated as the difference between

\begin{tabular}{|c|c|}
\hline Diet composition & Concentration \\
\hline \multicolumn{2}{|l|}{ Ingredient } \\
\hline Corn silage, $\mathrm{g} / \mathrm{kg}$ of $\mathrm{DM}$ & 325 \\
\hline Grass silage, $\mathrm{g} / \mathrm{kg}$ of DM & 181 \\
\hline Hay, $\mathrm{g} / \mathrm{kg}$ of DM & 32 \\
\hline Straw, g/kg of DM & 38 \\
\hline Corn kernels, $\mathrm{g} / \mathrm{kg}$ of DM & 70 \\
\hline Concentrate MF $2000,{ }^{1} \mathrm{~g} / \mathrm{kg}$ of DM & 220 \\
\hline Grain mix, $\mathrm{g} / \mathrm{kg}$ of DM & 39 \\
\hline Extracted soy meal, g/kg of DM & 21 \\
\hline Extracted canola meal, g/kg of DM & 38 \\
\hline Molassed sugar beet pulp, g/kg of DM & 23 \\
\hline Mineral/vitamin mix, ${ }^{2} \mathrm{~g} / \mathrm{kg}$ of DM & 9 \\
\hline Lime, $\mathrm{g} / \mathrm{kg}$ of DM & 4 \\
\hline \multicolumn{2}{|l|}{ Nutrient composition } \\
\hline Crude fat, $\mathrm{g} / \mathrm{kg}$ of DM & 31 \\
\hline $\mathrm{CP}, \mathrm{g} / \mathrm{kg}$ of $\mathrm{DM}$ & 152 \\
\hline Crude fiber, $\mathrm{g} / \mathrm{kg}$ of DM & 168 \\
\hline Starch, $\mathrm{g} / \mathrm{kg}$ of DM & 247 \\
\hline Ash, g/kg of DM & 69 \\
\hline \multicolumn{2}{|l|}{ Energy content } \\
\hline GE, MJ/kg of DM & 17.0 \\
\hline $\mathrm{ME}, \mathrm{MJ} / \mathrm{kg}$ of DM & 11.2 \\
\hline
\end{tabular}
$\mathrm{EE}$ and the mean of the 10 lowest $\mathrm{EE}$ values over the day, which are an estimate of resting EE. The mean EE measured during the last $30 \mathrm{~min}$ of the feed restriction period on d $2\left(\mathrm{EE}_{\text {rest }}\right)$ and $\mathrm{EE}_{\text {act }}$ was used to calculate diet-induced thermogenesis (DIT) according to

Table 1. Ingredients and nutrient composition of diet

${ }^{1} 33 \%$ extracted soy meal, $20 \%$ corn, $17 \%$ wheat gluten, $13 \%$ wheat, $8 \%$ extracted rapeseed meal, $5 \%$ sugar beet pulp, $2 \%$ sodium hydrogen carbonate, $1.3 \%$ calcium carbonate, and $0.2 \%$ sodium chloride (Vollkraft Mischfutterwerke GmbH, Güstrow, Germany).

${ }^{2}$ Rinderstolz 9522 Salvana (Tierernährung, Kl.-O. Sparrieshoop, Germany; per kg of feed; $88 \%$ DM): $39.3 \%$ calcium carbonate, $21.7 \%$ monocalcium phosphate, $21 \%$ sodium chloride, $11.9 \%$ magnesium oxide, and 2\% sugar beet molasses. Composition: $92 \%$ crude ash, $20 \%$ calcium, $8 \%$ sodium, $6 \%$ magnesium, $5 \%$ phosphorus, 1,000,000 IU of vitamin A, 200,000 IU of vitamin $\mathrm{D}_{3}$, and $4,500 \mathrm{mg}$ of vitamin E. No information on trace minerals was provided by the supplier. 


$$
\operatorname{DIT}(\mathrm{kJ})=\mathrm{EE}-\mathrm{EE}_{\text {rest }}-\mathrm{EE}_{\text {act }} .
$$

Loss of body tissue energy or energy balance (EB) for each stage of lactation during ad libitum feeding was calculated according to Kirkland et al. (2002):

$$
\mathrm{EB}(\mathrm{kJ})=\mathrm{MEI}(\mathrm{kJ})-\mathrm{EE}(\mathrm{kJ})-\mathrm{ECM}(\mathrm{kJ}) .
$$

Urine $\mathrm{N}$ excretion $\left(\mathrm{N}_{\mathrm{u}}\right)$ was not measured but estimated to $50 \mathrm{~g} / \mathrm{d}$, although real $\mathrm{N}_{\mathrm{u}}$ may amount to 75 to 150 $\mathrm{g} / \mathrm{d}$ (Dijkstra et al., 2013), thereby accepting an error of about $0.4 \%$ in the absolute $\mathrm{EE}$ values. Animals were milked twice daily (0630 and $1630 \mathrm{~h}$ ). Milk yield was recorded and samples from the evening and subsequent morning milking were pooled and sent to the Milk Testing Laboratory (Güstrow, Germany) for the analyses of milk fat, protein, and lactose using infrared spectrophotometry (MilkoScan, Foss GmbH, Rellingen, Germany) to calculate ECM as follows:

$$
\begin{gathered}
\operatorname{ECM}(\mathrm{kg})=[38 \times \text { fat }(\mathrm{g})+24 \times \text { protein }(\mathrm{g}) \\
+17 \times \text { lactose }(\mathrm{g})] \times \text { milk }(\mathrm{kg}) / 3,140 \\
\operatorname{ECMe}(\mathrm{kJ})=[38 \times \text { fat }(\mathrm{g})+24 \times \text { protein }(\mathrm{g}) \\
\quad+17 \times \text { lactose }(\mathrm{g})] \times \text { milk }(\mathrm{kg}) .
\end{gathered}
$$

To assess the relationship between MEI, milk energy (ECMe), and EB, multiple regression analysis was performed on a per unit mBW basis $\left[\mathrm{kJ} /\left(\mathrm{kg}^{0.75} \mathrm{~d}\right)\right]$ according to Kirkland et al. (2002):

$$
\begin{gathered}
\mathrm{ECMe} / \mathrm{mBW}=\mathrm{a}+\mathrm{b}(\mathrm{MEI} / \mathrm{mBW}) \\
+\mathrm{c}(\mathrm{EB} / \mathrm{mBW})\left[\mathrm{kJ} /\left(\mathrm{kg}^{0.75} \mathrm{~d}\right)\right],
\end{gathered}
$$

where $b$ provides an estimate of the efficiency of $\mathrm{ME}$ used for ECM production $\left(\mathrm{k}_{1}\right)$, and if EB is negative, the coefficient $\mathrm{c}$ is an estimate of the efficiency of tissue energy mobilization for ECM production $\left(\mathrm{k}_{\mathrm{lt}}\right)$.

The quotient $-\mathrm{a} / \mathrm{b}$ is an estimate of maintenance energy requirement $\left(\mathbf{M E}_{\mathrm{m}}\right)$ :

$$
\mathrm{ME}_{\mathrm{m}} / \mathrm{mBW}=-\mathrm{a} / \mathrm{b}\left[\mathrm{kJ} /\left(\mathrm{kg}^{0.75} \mathrm{~d}\right)\right] .
$$

The coefficients determined in equation [9] and $\mathrm{ME}_{\mathrm{m}}$ obtained from equation [10] were used to calculate the partitioning of milk production from intake and tissue mobilization, respectively:

$$
\begin{aligned}
& \mathrm{MEIM} / \mathrm{mBW}=\mathrm{MEI} / \mathrm{mBW} \\
& -\mathrm{ME}_{\mathrm{m}} / \mathrm{mBW}\left[\mathrm{kJ} /\left(\mathrm{kg}^{0.75} \mathrm{~d}\right)\right]
\end{aligned}
$$

in which MEIM is the portion of MEI used for milk production.

$$
\begin{gathered}
\mathrm{ECMe}_{\text {int }} / \mathrm{mBW}=\mathrm{MEIM} / \mathrm{mBW} \\
\times \mathrm{k}_{1}\left[\mathrm{~kJ} /\left(\mathrm{kg}^{0.75} \mathrm{~d}\right)\right], \\
\mathrm{ECMe}_{\text {tiss }} / \mathrm{mBW}=\mathrm{ECMe} / \mathrm{mBW} \\
-\mathrm{ECMe}_{\text {int }} / \mathrm{mBW}\left[\mathrm{kJ} /\left(\mathrm{kg}^{0.75} \mathrm{~d}\right)\right],
\end{gathered}
$$

in which $\mathrm{ECMe}_{\text {int }}$ and $\mathrm{ECMe}_{\text {tiss }}$ are the milk energy produced from feed intake and tissue mobilization, respectively.

$$
\begin{gathered}
\mathrm{EEM}_{\text {int }} / \mathrm{mBW}=\mathrm{MEIM} / \mathrm{mBW} \\
\times\left(1-\mathrm{k}_{\mathrm{l}}\right)\left[\mathrm{kJ} /\left(\mathrm{kg}^{0.75} \mathrm{~d}\right)\right] \\
\mathrm{EEM}_{\mathrm{tiss}} / \mathrm{mBW}=\mathrm{EB} / \mathrm{mBW} \\
\times\left(1-\mathrm{k}_{\mathrm{lt}}\right)\left[\mathrm{kJ} /\left(\mathrm{kg}^{0.75} \mathrm{~d}\right)\right]
\end{gathered}
$$

in which $\mathrm{EEM}_{\text {int }}$ and $\mathrm{EEM}_{\text {tiss }}$ are the energy expenditure of milk production from feed intake and tissue mobilization, respectively.

$$
\begin{aligned}
\mathrm{ECM}_{\text {int }} & =\mathrm{ECMe}_{\text {int }} / 3,140(\mathrm{~kg}) \\
\mathrm{ECM}_{\text {tiss }} & =\mathrm{ECMe}_{\text {tiss }} / 3,140(\mathrm{~kg})
\end{aligned}
$$

where $\mathrm{ECM}_{\text {int }}$ and $\mathrm{ECM}_{\text {tiss }}$ are the energy-corrected milk yield produced from feed intake and tissue mobilization, respectively.

In addition and alternatively to the use of equation [9], $\mathrm{k}_{\mathrm{lt}}$ was also calculated by

$$
\mathrm{k}_{\mathrm{lt}}=\mathrm{ECM}_{\mathrm{tiss}} /-\mathrm{EB}
$$

for stages in negative EB.

\section{Statistical Analyses}

To identify individual animals of similar metabotype, hierarchical cluster analysis was performed using the Ward method in JMP (version 12.0.1, SAS Institute Inc., Cary, NC). Animals were clustered using the 3 metabotype characterizing variables $\mathrm{MEI} / \mathrm{mBW}$, $\mathrm{V}_{\mathrm{CO} 2 \text { metab }} / \mathrm{mBW}$, and $\mathrm{V}_{\mathrm{O} 2} / \mathrm{mBW}$ as measured at wk 5 pp during ad libitum feeding, because it was assumed that the greatest metabolic differences occurred in early lactation. Based on the obtained dendrogram, cows clustered into 3 groups consisting of 9, 7, and 2 animals (Figure 1). Because of the similarity of 2 of the clusters, groups with the 7 and 2 animals were unified to one group, yielding 2 groups of each 9 cows. Animals clus- 


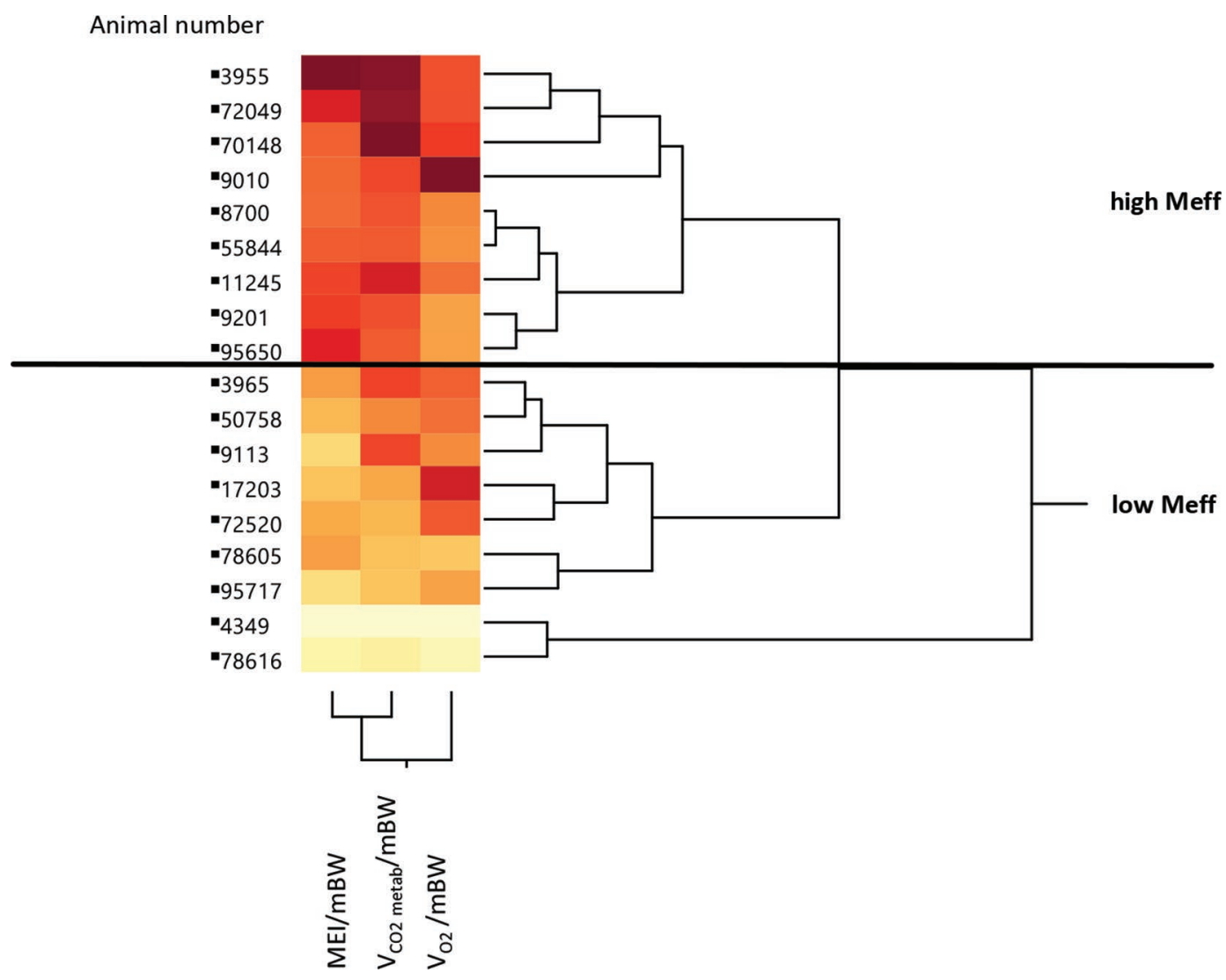

Figure 1. Hierarchical clustering of 18 cows according to metabolizable energy intake (MEI), metabolic $\mathrm{CO}_{2}$ production, and $\mathrm{O}_{2}$ consumption per kilogram of metabolic body weight $(\mathrm{mBW})$ at wk 5 postpartum. The numbers on the $\mathrm{y}$-axis refer to the animal number, and the order reflects their rank. Colors code for $\mathrm{MEI} / \mathrm{mBW}, \mathrm{V}_{\mathrm{CO} 2 \text { metab }} / \mathrm{mBW}$, and $\mathrm{V}_{\mathrm{O} 2} / \mathrm{mBW}$ values, respectively, with dark red illustrating the highest and light yellow the lowest value in each column. $\mathrm{V}_{\mathrm{CO} 2 \text { metab }}=$ volume of produced metabolic $\mathrm{CO}_{2} ; \mathrm{V}_{\mathrm{O} 2}=$ volume of $\mathrm{O}_{2}$ consumed. Low Meff $=$ low metabolic efficiency; high Meff = high metabolic effiiciency.

tering to high $\mathrm{MEI} / \mathrm{mBW}, \mathrm{V}_{\mathrm{CO} 2 \text { metab }} / \mathrm{mBW}$, and $\mathrm{V}_{\mathrm{O} 2} /$ $\mathrm{mBW}$ values were considered as being low metabolic efficient (low-Meff), whereas those with low MEI/ $\mathrm{mBW}, \mathrm{V}_{\mathrm{CO} 2 \text { metab }} / \mathrm{mBW}$, and $\mathrm{V}_{\mathrm{O} 2} / \mathrm{mBW}$ were classified as being high metabolic efficient (high-Meff).

Statistical analysis was performed using a 2-way repeated measures ANOVA model with the fixed factor group (high-Meff and low-Meff), the repeated factor time (wk 5, 13, and 42), and the interaction of group $\times$ time using the MIXED procedure of SAS (SAS Systems, version 9.4, SAS Institute Inc., Cary, NC). To evaluate the differences between the 2 groups at each time, the SLICE option of PROC MIXED was used. The covariance was modeled as unstructured. All statistical tests were performed for a significance level of $P$ $<0.05$. A trend was considered at $P<0.1$.

\section{RESULTS}

Contrary to the clustering criteria, $\mathrm{V}_{\mathrm{O} 2} / \mathrm{mBW}$ did not differ between cow groups, but in accordance with the presetting, high-Meff cows had lower $\mathrm{MEI} / \mathrm{mBW}$ and $\mathrm{V}_{\mathrm{CO} 2 \text { metab }} / \mathrm{mBW}$ compared with low-Meff cows at wk 5 pp $(P<0.05$; Table 2$)$. However, these group differences did not exist at wk 13 and $42 \mathrm{pp}$. The difference in $\mathrm{MEI} / \mathrm{mBW}$ at wk 5 after calving was not due to differences in BW, but MEI and DMI, respectively, were lower in high-Meff compared with low-Meff cows $(P<$ 0.05). High-Meff cows produced less metabolic $\mathrm{CO}_{2}(P$ $<0.05)$ and tended to have a lower $\mathrm{RQ}_{\text {metab value }}(P$ $=0.06)$ at wk $5 \mathrm{pp}$, whereas these differences were not apparent at wk 13 and $42 \mathrm{pp}$. Both cow groups did not differ in daily $\mathrm{O}_{2}$ consumption, but $\mathrm{CH}_{4}$ production, $\mathrm{CH}_{4} / \mathrm{mBW}$, and $\mathrm{CH}_{4} / \mathrm{ECM}$ were lower in high-Meff relative to low-Meff counterparts at wk 5 and 13 pp $(P$ $<0.05)$, whereas $\mathrm{CH}_{4}$ yield $\left(\mathrm{CH}_{4} / \mathrm{DMI}\right)$ did not differ between groups. In addition, the number of DIM when measured in chambers, milk constituents, and ECM were not different between cow groups; however, FCE was higher in high-Meff than low-Meff cows at wk 5 and $13 \mathrm{pp}(P<0.05)$. Vice versa, RMEI and the EB was always lower in high-Meff compared with low-Meff 
cows $(P<0.05)$. Diet-induced thermogenesis DIT/ $\mathrm{mBW}$ and heat production expressed as $\mathrm{EE} / \mathrm{mBW}$ were lower in high-Meff cows at wk 5 but not wk 13 and $42 \mathrm{pp}(P<0.05)$. No differences were observed in heat production during ad libitum feeding (EE) or after the $24 \mathrm{~h}$-feed restriction period $\left(\mathrm{EE}_{\text {rest }} / \mathrm{mBW}\right)$ between groups, but BW loss after the $24 \mathrm{~h}$-feed restriction period increased from wk 5 to wk $42 \mathrm{pp}$. Interestingly, loss of BW after feed restriction was significantly higher in high-Meff cows $\left(P_{\text {group }}<0.05\right)$. With the exception of total $\mathrm{O}_{2}$ consumption, all variables tended to change $\left(P_{\text {time }}<0.1\right)$ or changed $\left(P_{\text {time }}<0.05\right)$ from wk 5 to 42 pp without significant group $\times$ time interactions.

As each of the divergent efficiency groups consisted of only 9 cows, multiple-regression analysis was performed for each time point including all 18 cows. As a result, the constant a ranged between -516.2 and -446.1 , coefficient $\mathrm{b}$ between 0.65 and 0.69 , and coefficient $\mathrm{c}$ between -0.73 and -0.84 (Table 3 ). Each of the 3 regression models had an adjusted $\mathrm{R}^{2}$ value of 0.95 . By using the 3 regression models, daily $\mathrm{ME}_{\mathrm{m}} / \mathrm{mBW}$ was calculated to amount to 743,686 , and $738 \mathrm{~kJ} / \mathrm{kg}^{0.75}$ for wk 5,13 , and $42 \mathrm{pp}$, respectively. With these values, the MEIM was calculated for each group and found to be lower in high-Meff cows at wk 5 pp $(P<0.05)$. Moreover, the comparison between the absolute value of coefficient $\mathrm{c}$ obtained from the regression model (equation [9]) and the $\mathrm{k}_{\mathrm{lt}}$ value calculated by equation [18] revealed good agreement of both estimates.

Next, the regression models were used to calculate several measures of metabolic efficiency of milk production for each of the 2 groups. The portion of milk produced from feed intake $\left(\mathrm{ECM}_{\mathrm{int}}\right)$ as well as the portion of milk energy produced per unit $\mathrm{mBW}$ from feed intake $\left(\mathrm{ECMe}_{\text {int }} / \mathrm{mBW}\right)$ were lower in high-Meff than low-Meff cows at wk 5 pp $(P<0.05)$ and peaked at wk 13 for both groups $\left(P_{\text {time }}<0.05\right)$. On the other hand, the portion of milk produced from endogenous tissue sources $\left(\mathrm{ECM}_{\text {tiss }}\right)$ and the milk energy produced per $\mathrm{mBW}$ from tissue $\left(\mathrm{ECMe}_{\text {tiss }} / \mathrm{mBW}\right)$ were greater in high-Meff than low-Meff cows at wk 5 and $13(P<$ $0.05)$ and declined in both groups by wk $42 \mathrm{pp}\left(P_{\text {time }}<\right.$ $0.05)$. The $\mathrm{ECMe}_{\text {int }} / \mathrm{ECMe}_{\text {tiss }}$ ratio was even lower than 1 in high-Meff cows 5 wk after calving and increased with progressing time after calving in both groups $\left(P_{\text {time }}<0.05\right)$. The energy expended for milk production from feed intake $\left(\mathrm{EEM}_{\mathrm{int}} / \mathrm{mBW}\right)$ was significantly lower in high-Meff than low-Meff cows at wk 5 pp $(P$ $<0.05$ ), whereas no differences were observed at later time points. The energy expended for milk production from mobilized tissue $\left(\mathrm{EEM}_{\text {tiss }} / \mathrm{mBW}\right)$ was not different between groups at any of the 3 stages, but there was an overall group effect with higher values in high-Meff cows $\left(P_{\text {group }}<0.05\right)$. To verify this result, we calculated $\mathrm{EEM}_{\text {tiss }} / \mathrm{mBW}$ (equation [15]) using the $\mathrm{k}_{\mathrm{lt}}$ value determined from the regression equation [9] and calculated from equation [18]. The results based on the $\mathrm{k}_{\mathrm{lt}}$ value obtained from equation [18] revealed that $\mathrm{EEM}_{\text {tiss }} / \mathrm{mBW}$ was higher $(P<0.05)$ or tended to be higher $(P=0.08)$ for high-Meff cows at all time points after calving. In addition, the accuracy of the regression model was examined by calculating the sum of $\mathrm{ME}_{\mathrm{m}}$ $+\mathrm{EEM}_{\mathrm{int}}+\mathrm{EEM}_{\text {tiss }}$ (Table 3), where the summands were obtained from the equations [10], [14], and [15]. The sum calculated equals to $\mathrm{EE} / \mathrm{mBW}$ and is almost identical to the value measured by indirect calorimetry with lower numbers of high-Meff cows at wk 5 pp.

Plasma NEFA, concentrations as markers for adipose tissue mobilization, respectively, were not different between groups, but plasma glucose concentrations tended to be $(P=0.06)$ or were lower in high-Meff cows at wk 5 and $13 \mathrm{pp}(P<0.05$; Table 4$)$. Plasma triglyceride concentrations as an indicator of fat transfer into milk and BHB concentrations reflecting ketosis were also not different between cow groups. In addition, low-Meff cows tended to have a higher relative German breeding value functional herd life as compared with high-Meff cows (118 \pm 4 vs. $107 \pm 4 ; P=0.1)$, whereas the German relative breeding value milk production (Masterrind, 2019) did not differ between groups (117 \pm 2 vs. $117 \pm 4 ; P=0.96)$.

\section{DISCUSSION}

\section{Clustering Results and Maintenance Energy Requirement}

The objectives of the study were to assess whether variables of energy expenditure account for the variation in metabolic efficiency of dairy cows and whether differences in these variables persist at various stages after calving. To approach this aim, we clustered 18 cows according to the 3 measured variables MEI, $\mathrm{O}_{2}$ consumption, and metabolic $\mathrm{CO}_{2}$ production, each normalized to the $\mathrm{mBW}$, because a complex trait such as metabolic efficiency is difficult to define by a sole variable only. We found that the 18 cows could be separated in 2 groups with high-Meff cows exhibiting less MEI/ $\mathrm{mBW}$ and $\mathrm{V}_{\mathrm{CO} 2 \text { metab }} / \mathrm{mBW}$ than low-Meff cows despite of their comparable BW and ECM production. However, $\mathrm{O}_{2}$ consumption as another clustering criterion was not different between these groups, which seem to contrast earlier reported differences in splanchnic tissue $\mathrm{O}_{2}$ consumption per mBW between high and low FCE steers (Hersom et al., 2003). On the other hand, $\mathrm{O}_{2}$ consumption alone was assessed to be an insufficient marker of energy metabolism, as rather the amount of ATP generated per oxygen atom $(\mathrm{P} / \mathrm{O}$ ratio) by the 
METABOLIC EFFICIENCY OF DAIRY COWS

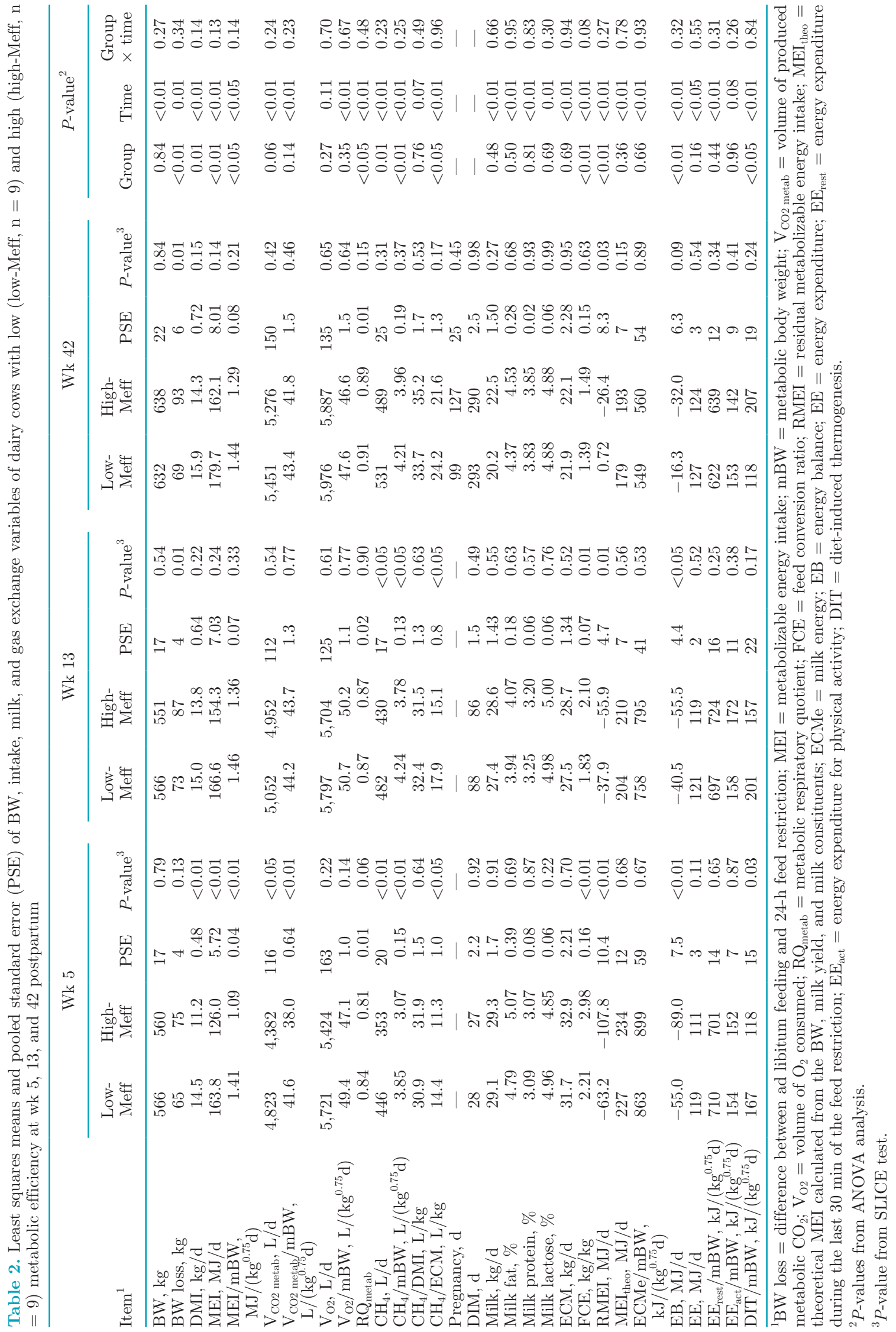


DERNO ET AL.

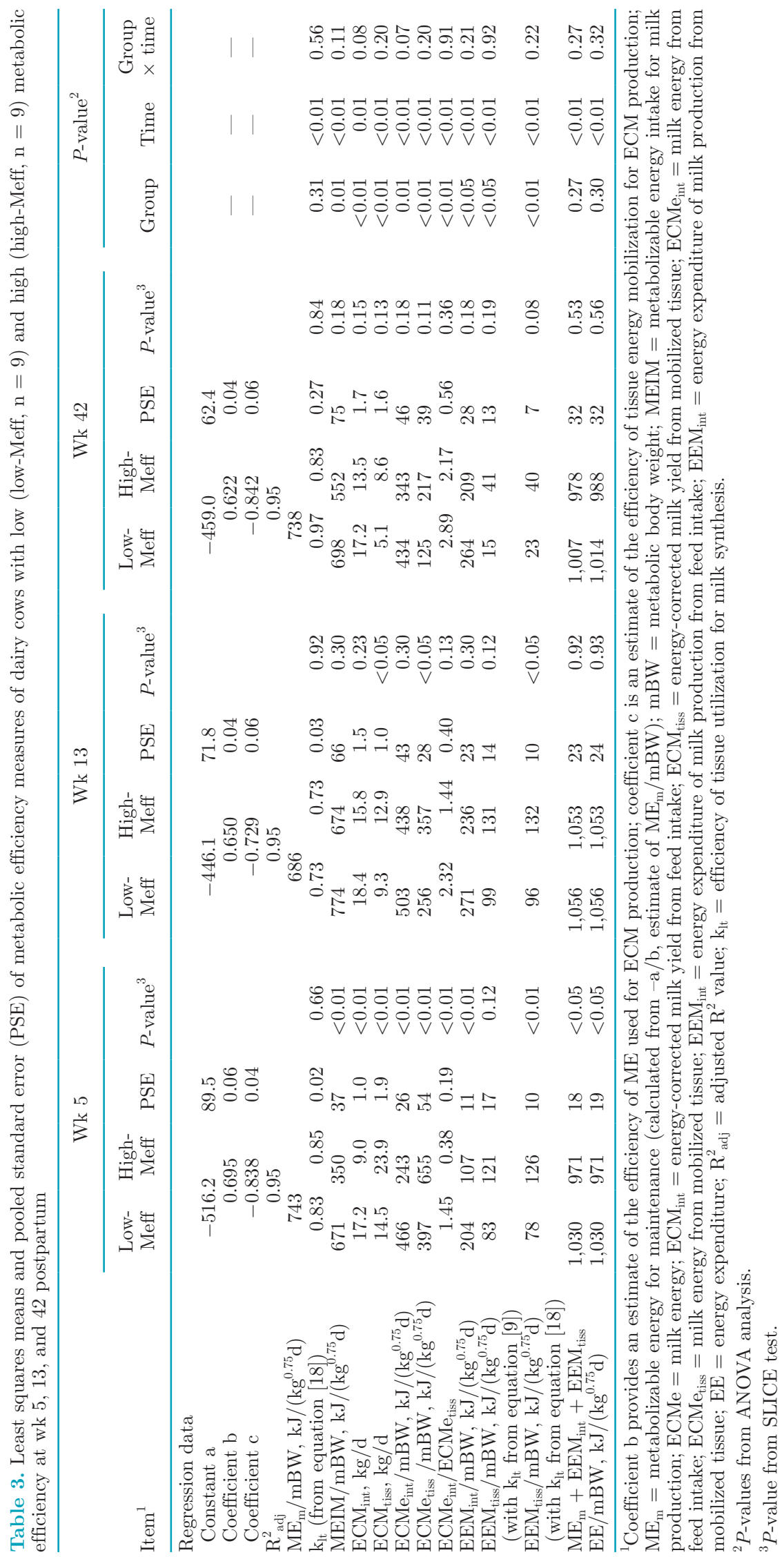


mitochondria determines the efficiency of cellular energy production (Salin et al., 2015). There are numerous molecular reasons for the between-animal variation in the $\mathrm{P} / \mathrm{O}$ ratio and metabolic efficiency, among them the greater uncoupling of the electron transport chain leading to a higher proton leakage across the inner mitochondrial membrane and reactive oxygen species (ROS) production (Salin et al., 2015). Although some of these molecular mechanisms were identified for various monogastric species and beef cattle differing in feed efficiency (Bottje and Carstens, 2009; CantalapiedraHijar et al., 2018), comprehensive studies in dairy cows have not been performed. However, it is tempting to speculate that a lower German breeding value functional herd life of high-Meff cows may be due to higher ROS levels and lower ATP production efficiency.

The higher MEI/mBW of low-Meff cows seem to exist across all stages after calving $\left(P_{\text {group }}<0.05\right)$, but was significantly different only at wk $5 \mathrm{pp}(P<0.01)$, whereas ECM was comparable to high-Meff cows during all stages investigated. This result suggests that low-Meff cows, which had higher DMI and thus MEI, use a smaller portion of feed energy for milk production, maintenance, or both. Maintenance energy $\left(\mathrm{ME}_{\mathrm{m}}\right)$ deduced from regression analysis was not calculated for both groups separately because of the limited number of animals; however, $\mathrm{EE}_{\text {rest }} / \mathrm{mBW}$ as an estimate of maintenance heat production was not different between groups, suggesting that $\mathrm{ME}_{\mathrm{m}}$ was also not different among groups. Our finding supports the results of an earlier study in which $\mathrm{ME}_{\mathrm{m}}$ values for Holstein Friesian cows, Holstein Friesian crossbreds, and Norwegian dairy cows at various stages of lactation were not different between these breeds and amounted to $686 \pm 16$ $\mathrm{kJ} /\left(\mathrm{kg}^{0.75} \mathrm{~d}\right.$ ) (Dong et al., 2015), which is comparable to the data obtained in the present study. However, the discrepancy between $\mathrm{ME}_{\mathrm{m}}$ determined by the regression model (equations [9] and [10]) with the lowest value at wk $13 \mathrm{pp}$ and the experimentally measured $\mathrm{EE}_{\text {rest }}$, which was lowest at wk $42 \mathrm{pp}$, can be explained by the fact that under experimental fasting conditions cows still produce milk and associated heat, whereas the calculation of $\mathrm{ME}_{\mathrm{m}}$ presumes that ECM and EB are zero.

It is interesting to note that $\mathrm{EE}_{\text {rest }} / \mathrm{mBW}$ values were greater at wk 5 and 13 than wk 42 pp as these data indicate that fasting heat production and maintenance energy requirement are not constant over the course of lactation. Dong et al. (2015) reported that the energy for maintenance is positively related to ME intake with an increase in $\mathrm{ME}_{\mathrm{m}}$ of 62 to $65 \mathrm{~kJ} /\left(\mathrm{kg}^{0.75} \mathrm{~d}\right)$ when $\mathrm{ME}$ increases by $1,000 \mathrm{~kJ} / \mathrm{kg}^{0.75}$. Other authors reported that maintenance energy is a function of body protein mass rather than BW or energy intake (Agnew and Yan, 2000). Hence, the intensive fat mobilization dur- 
ing the first 5 wk of lactation, which is 4 to 10 times greater than the amount of protein mobilization (Komaragiri et al., 1998), results in a higher body protein content, which should additionally account for an increase in maintenance energy requirements. Moreover, blood fluxes and $\mathrm{O}_{2}$ consumption in the portal-drained viscera and liver continuously increased from d 11 to 83 after calving (Reynolds et al., 2003), further indicating increasing energy requirements for maintenance. However, various recent energy feeding systems consider $\mathrm{ME}_{\mathrm{m}}$ to depend only on BW and energy for physical activity [e.g., NRC (2001), GfE (2004), NorFor (2011), and INRA (2018)], irrespective of the level of tissue mobilization, DMI, or milk production. Thus, particularly in early- and mid-lactation stages, energy requirements for maintenance of high-producing dairy cows seem to be underestimated and EB overestimated (Dong et al., 2015).

\section{Thermic and $\mathrm{CH}_{4}$ Energy Losses}

The low-Meff cows had greater DIT and heat production $(\mathrm{EE} / \mathrm{mBW})$ in early lactation, suggesting that the thermic effect of feed and greater metabolic heat losses account for the smaller portion of MEI available for milk production and thus the lower FCE in low-Meff cows. Comparably, low-FCE beef cattle had greater heat production and $32 \%$ higher heat increment of feeding (equals to DIT) than high-FCE cattle (Nkrumah et al., 2006), and low-FCE cows had greater heat production than cows with a higher FCE (Arndt et al. (2015). Therefore, low-FCE animals seem to be more prone to suffer from high ambient temperatures than high-FCE counterparts in times of hot weather periods. In addition, low-Meff cows had higher $\mathrm{CH}_{4}$ production and $\mathrm{CH}_{4} / \mathrm{mBW}$ than high-Meff cows, again indicating that a smaller portion of ingested feed was available for milk production in these animals. Comparable to our results, Nkrumah et al. (2006) and Arndt et al. (2015) also found less $\mathrm{CH}_{4}$ energy losses in high-FCE cows and low-RFI cattle, respectively. On the other hand, $\mathrm{CH}_{4}$ yield as well as rumen acetate, propionate, and butyrate concentrations (data not shown) did not differ between high-Meff and low-Meff cows in the present study, indicating that the ruminal fermentation characteristics were not different between efficiency groups. This conclusion is supported by the study of Potts et al. (2017), who described that the digestive ability of low-RFI and high-RFI cows on a diet containing 30.1\% starch per $\mathrm{kg}$ of DM is not different between groups and the starch level fed in the present study $(24.7 \%)$ was only marginally smaller. Our conclusion further agrees with Arndt et al. (2015), stating that the marginally lower digestive efficiency of high-FCE cows in mid and late lactation is more than compensated for by greater metabolic efficiencies.

\section{Energy Partitioning for Milk Production}

Based on equation [9], we calculated the efficiency of ME used for milk production $\left(\mathrm{k}_{1}\right)$ and found decreasing values from wk 5 to $42 \mathrm{pp}$. Or result is line with a the study of Kirkland and Gordon (2001) who reported that early lactating cows partitioned a significantly greater proportion of MEI to milk energy compared with cows in mid or late lactation. Interestingly, highMeff cows utilized less metabolizable energy intake for milk and milk energy production (MEIM/mBW and $\left.\mathrm{ECMe}_{\text {int }} / \mathrm{mBW}\right)$ from wk 5 to $42\left(P_{\text {group }}=0.01\right)$ with the largest difference between efficiency groups at wk 5 pp $(P<0.01)$. Vice versa, high-Meff cows produced a higher portion of ECM from mobilized tissue (EC$\mathrm{M}_{\text {tiss }}$ and $\mathrm{ECM}_{\text {tiss }} / \mathrm{mBW}$ ) compared with low-Meff cows and this difference was predominantly evident until wk 13 after calving $(P<0.05)$. Thus, high-Meff cows prefer utilizing endogenous rather than dietary energy sources, and their greater metabolic efficiency must be determined by differences in fuel selection. One reason for the preferred utilization of, for example, mobilized fat reserves of high-Meff cows is the energy saving for milk fat synthesis. The energy conversion efficiency of feed-derived acetate or butyrate for the production of 1 mol palmitate by the mammary gland amounts to only 75 to $79 \%$ relative to endogenous palmitate utilization and requires 15 to $11 \mathrm{~mol}$ ATP, respectively (Bergner and Hoffmann, 1996). However, high-Meff and lowMeff cows did not significantly differ in milk fat and plasma NEFA concentrations, but the latter declined from wk 5 to 42 , suggesting that endogenous fat utilization is important for milk fat synthesis for both groups particularly in early lactation. Besides, the oxidation of fat compared with carbohydrate yields approximately $15 \%$ more ATP, which is required for de novo syntheses (Salin et al., 2015).

Other energy-saving mechanisms than endogenous fat utilization must cause the difference in tissue utilization between efficiency groups. High-Meff cows tended to have lower plasma glucose concentrations at wk 5 pp than low-Meff cows. Whether high-Meff cows had a lower glycogen reservoir, less de novo glucose synthesis, or used more glucose for energy and milk production can only be speculated. The glycogen reserves primarily stored in muscle and liver become exhausted within the first $40 \mathrm{~d}$ of lactation (Schäff et al., 2012) and the mobilization of endogenous glucogenic substrates, primarily lactate, glycerol, and AA, gain importance for gluconeogenesis (Aschenbach et al., 2010). The energy conversion efficiency of glucose converted to $1 \mathrm{~mol}$ pal- 
mitate is greater than $85 \%$ and requires only $7 \mathrm{~mol}$ ATP (Bergner and Hoffmann, 1996). In addition, the synthesis of casein from AA and glucose requires $18 \%$ less energy than from AA and feed-derived propionate ( 0.26 vs. $0.34 \mathrm{~kJ} / \mathrm{kg}$ of casein; Bergner and Hoffmann, 1996). Thus, the superior utilization of endogenous energy reserves, particularly of fat and endogenous glucogenic substrates, for milk production early after calving indicates an energy-sparing mechanism making high-Meff cows metabolically more efficient. The ingestion of less feed but greater use of tissue energy early after calving may be an evolutionary conserved advantage for the calf receiving more energy from the dam but also compromises health, immunity, and EB of the mother, and these compromises are lifted when the calf reduces suckling. Interestingly, dairy cows with a deeper negative EB in early lactation usually ingest less feed and have lower plasma glucose concentrations than cows ingesting more feed but in a less pronounced negative EB (Kuhla et al., 2016). However, it seems surprising that cows in both groups are still in a mild negative $\mathrm{EB}$ at wk $42 \mathrm{pp}$, although their BW increased by 66 to $87 \mathrm{~kg}$ relative to wk $13 \mathrm{pp}$. This apparent discrepancy can be explained by the greater rumen-intestinal fill at wk 42. At this time point, cows had a higher DMI compared with wk 13. Additionally, the loss of BW after the 24-h feed restriction amounted to 69 to $93 \mathrm{~kg}$, which is comparable to the $\mathrm{BW}$ increase relative to $\mathrm{wk}$ 13. Interestingly, high-Meff cows lost more BW during feed restriction, suggesting that metabolically efficient cows have a higher propensity for tissue mobilization than low-Meff cows. Whether cow groups differ also in their rumen-intestinal volume can only be speculated. However, although the amount of tissue energy for ECM production was greater in high-Meff cows, the efficiency of tissue utilization for milk synthesis $\left(\mathrm{k}_{\mathrm{lt}}\right)$ was not. Constant efficiency of utilization of mobilized tissue ranging between 0.82 and 0.84 was documented earlier by comparing different feeding systems (Agnew et al., 2003).

\section{Similarities and Controversy Between Feed and Metabolic Efficiency}

Most definitions of feed efficiency account for the instantaneous use of feed for product generation. As such, dairy cows with low DMI and high ECM yield would account as highly feed efficient (high FCE, low RFI, or low RMEI value), regardless of the source of energy originating either from tissue reserves or feed. In the present study, we identified high-Meff cows possessing a higher FCE and lower RMEI value to produce less methane than low-Meff cows at wk 5 and 13 pp. Therefore, selecting low $\mathrm{CH}_{4}$ emitting animals in an attempt to select for greater feed efficiency must be carefully considered as this may result in greater apparent feed and metabolic efficiency with a lower portion of feed energy converted into milk.

\section{CONCLUSIONS}

The current study demonstrated that by using MEI, $\mathrm{O}_{2}$, and $\mathrm{CO}_{2}$, each normalized to $\mathrm{mBW}$, divergent metabolic efficient cows can be distinguished by a cluster approach. At a comparable level of ECM yield, the greater metabolic efficiency of high-Meff cows can be attributed to lower energy losses by heat and methane production, greater utilization of energy from body reserves, and proportionally less utilization of feed energy for milk synthesis as compared with low-Meff cows. Whereas these differences were primarily evident during the early lactation period up to wk $13 \mathrm{pp}$, they did not persist until wk 42 after calving, indicating that the individual metabolic efficiency trait is not persistent across the whole lactation cycle. Different metabolic efficiency traits could not be assigned to differences in metabolizable energy for maintenance $\left(\mathrm{ME}_{\mathrm{m}}\right)$ or the efficiency of tissue utilization for milk synthesis $\left(\mathrm{k}_{\mathrm{lt}}\right)$. Future studies should explore whether the degree of metabolic efficiency of dairy cows is determined by the mitochondrial efficiency of ATP production, uncoupling of the electron transport chain, and associated ROS production, and examine if differences in these traits account for the tendency of lower German relative breeding value functional herd life as an indicator of productive lifespan of high-Meff cows.

\section{ACKNOWLEDGMENTS}

We thank H. Pröhl and the staff at the "Tiertechnikum" and the cattle experimental unit at the Leibniz Institute for Farm Animal Biology (FBN) in Dummerstorf (Germany) for animal care and handling, sample collection, and sample preparation. This study was conducted in frame of The Joint Programming Initiative on Agriculture, Food Security and Climate Change (FACCE-JPI) program and partially financed by the German Federal Ministry of Food and Agriculture (BMBL) through the Federal Office for Agriculture and Food (BLE), grant number 2814ERA04A, and partially funded by the core budget of the FBN. The publication of this article was funded by the Open Access Fund of the FBN.

\section{REFERENCES}

Agnew, R. E., and T. Yan. 2000. Impact of research on energy feeding systems for dairy cattle. Livest. Prod. Sci. 66:197-215. 
Agnew, R. E., T. Yan, J. J. Murphy, C. P. Ferrisa, and F. J. Gordon. 2003. Development of maintenance energy requirement and energetic efficiency for lactation from production data of dairy cows. Livest. Prod. Sci. 82:151-162.

Arndt, C., J. M. Powell, M. J. Aguerre, P. M. Crump, and M. A. Wattiaux. 2015. Feed conversion efficiency in dairy cows: Repeatability, variation in digestion and metabolism of energy and nitrogen, and ruminal methanogens. J. Dairy Sci. 98:3938-3950.

Aschenbach, J. R., N. B. Kristensen, S. S. Donkin, H. M. Hammon, and G. B. Penner. 2010. Gluconeogenesis in dairy cows: The secret of making sweet milk from sour dough. IUBMB Life. 62:869-877.

Bergner, H., and L. Hoffmann. 1996. Bioenergetik und Stoffproduktion landwirtschaftlicher Nutztiere. Harwood Academia Publishers, Amsterdam, the Netherlands.

Boguhn, J., H. Kluth, O. Steinhöfel, M. Peterhänsel, and M. Rodehutscord. 2003. Nutrient digestibility and prediction of metabolizable energy in total mixed rations for ruminants. Arch. Anim. Nutr. $57: 253-266$.

Bottje, W. G., and G. E. Carstens. 2009. Association of mitochondrial function and feed efficiency in poultry and livestock species. J. Anim. Sci. 87(Suppl):E48-E63.

Brouwer, E. 1965. Report of sub-committee on constants and factors K. L. Blaxter, ed. Pages 441-443 in Proceedings of the 3rd Symposium on Energy Metabolism. Academic Press, London, UK.

Cantalapiedra-Hijar, G., M. Abo-Ismail, G. E. Carstens, L. L. Guan, R. Hegarty, D. A. Kenny, M. McGee, G. Plastow, A. Relling, and I. Ortigues-Marty. 2018. Review: Biological determinants of between-animal variation in feed efficiency of growing beef cattle. Animal 12:s321-s335.

Capper, J. L., R. A. Cady, and D. E. Baumann. 2009. The environmental impact of dairy production: 1944 compared with 2007. J. Anim. Sci. 87:2160-2167.

Chwalibog, A., K. Jensen, and G. Thorbek. 1996. Oxidation of nutrients in bull calves treated with beta-adrenergic agonists. Arch. Anim. Nutr. Arch. Tierernahr. 49:255-261.

Derno, M., G. Nürnberg, P. Schön, A. Schwarm, M. Röntgen, H. M. Hammon, C. C. Metges, R. M. Bruckmaier, and B. Kuhla. 2013. Short-term feed intake is regulated by macronutrient oxidation in lactating Holstein cows. J. Dairy Sci. 96:971-980.

Dijkstra, J., O. Oenema, J. W. van Groenigen, J. W. Spek, A. M. van Vuuren, and A. Bannink. 2013. Diet effects on urine composition of cattle and $\mathrm{N}_{2} \mathrm{O}$ emissions. Animal 7(Suppl 2):292-302.

Dong, L. F., T. Yan, C. P. Ferris, and D. A. McDowell. 2015. Comparison of maintenance energy requirement and energetic efficiency between lactating Holstein-Friesian and other groups of dairy cows. J. Dairy Sci. 98:1136-1144.

GfE (German Society of Nutrition Physiology) Ausschuss für Bedarfsnormen der Gesellschaft für Ernährungsphysiologie). 2004. Empfehlungen zur Energie- und Nährstoffversorgung der Milchkühe und Aufzuchtrinder (Recommended energy and nutrient supply for dairy cows and growing cattle). Vol. 13. DLG-Verlag.

Hanrahan, L., N. McHugh, T. Hennessy, B. Moran, R. Kearney, M. Wallace, and L. Shalloo. 2018. Factors associated with profitability in pasture-based systems of milk production. J. Dairy Sci. 101:5474-5485.

Herd, R. M., and P. F. Arthur. 2009. Physiological basis for residual feed intake. J. Anim. Sci. 87:E64-E71.

Hersom, M. J., C. R. Krehbiel, G. W. Horn, and J. G. Kirkpatrick. 2003. Effect of the live weight gain of steers during winter grazing on digestibility, acid-base balance, blood flow, and oxygen consumption by splanchnic tissues during adaptation and subsequent feeding of a high-grain diet. J. Anim. Sci. 81:3130-3140.

Hurley, A. M., N. López-Villalobos, S. McParland, E. Kennedy, E. Lewis, M. O’Donovan, J. L. Burke, and D. P. Berry. 2016. Inter- relationships among alternative definitions of feed efficiency in grazing lactating dairy cows. J. Dairy Sci. 99:468-479.

INRA. 2018. INRA feeding system for ruminants. Wageningen Academic Publishers, Wageningen, the Netherlands.

Jewell, K. A., C. A. McCormick, C. L. Odt, P. J. Weimer, and G. Suen. 2015. Ruminal bacterial community composition in dairy cows is dynamic over the course of two lactations and correlates with feed efficiency. Appl. Environ. Microbiol. 81:4697-4710.

Kirkland, R. M., and F. J. Gordon. 2001. The effects of stage of lactation on the partitioning of, and responses to changes in, metabolisable energy intake in lactating dairy cows. Livest. Prod. Sci. 72:213-224.

Kirkland, R. M., T. Yan, R. E. Agnew, and F. J. Gordon. 2002. Efficiency of use of body tissue energy for milk production in lactating dairy cows. Livest. Prod. Sci. 73:131-138.

Koch, R. M., L. A. Swiger, D. Chambers, and K. E. Gregory. 1963. Efficiency of feed use in beef cattle. J. Anim. Sci. 22:486-494.

Komaragiri, M. V., D. P. Casper, and R. A. Erdman. 1998. Factors affecting body tissue mobilization in early lactation dairy cows. 2 . Effect of dietary fat on mobilization of body fat and protein. J. Dairy Sci. 81:169-175.

Kuhla, B., C. C. Metges, and H. M. Hammon. 2016. Endogenous and dietary lipids influencing feed intake and energy metabolism of periparturient dairy cows. Domest. Anim. Endocrinol. 56(Suppl):S2S10.

Masterrind. 2019. Breeding evaluation. https://www.masterrind.com/ en/bulls/breeding-evaluation/\#moverview.

Nkrumah, J. D., E. K. Okine, G. W. Mathison, K. Schmid, C. Li, J. A. Basarab, M. A. Price, Z. Wang, and S. S. Moore. 2006. Relationships of feedlot feed efficiency, performance, and feeding behavior with metabolic rate, methane production, and energy partitioning in beef cattle. J. Anim. Sci. 84:145-153.

NorFor. 2011. The Nordic Feed Evaluation System. H. Volden, ed. Wageningen Academic Publishers, Wageningen, the Netherlands.

NRC. 2001. Nutrient Requirements of Dairy Cattle. 7th rev. ed. Subcommittee on Dairy Cattle Nutrition, Committee on Animal Nutrition, Board on Agriculture and Natural Resources, National Research Council, National Academy Press, Washington, DC.

Potts, S. B., J. P. Boerman, A. L. Lock, M. S. Allen, and M. J. VandeHaar. 2017. Relationship between residual feed intake and digestibility for lactating Holstein cows fed high and low starch diets. J. Dairy Sci. 100:265-278.

Reynolds, C. K., P. C. Aikman, B. Lupoli, D. J. Humphries, and D. E. Beever. 2003. Splanchnic metabolism of dairy cows during the transition from late gestation through early lactation. J. Dairy Sci. 86:1201-1217

Rius, A. G., S. Kittelmann, K. A. Macdonald, G. C. Waghorn, P. H. Janssen, and E. Sikkema. 2012. Nitrogen metabolism and rumen microbial enumeration in lactating cows with divergent residual feed intake fed high-digestibility pasture. J. Dairy Sci. 95:50245034 .

Salin, K., S. K. Auer, B. Rey, C. Selman, and N. B. Metcalfe. 2015 Variation in the link between oxygen consumption and ATP production, and its relevance for animal performance. Proc. Biol. Sci. $282: 20151028$

Salter, A. M. 2017. Improving the sustainability of global meat and milk production. Proc. Nutr. Soc. 76:22-27.

Schäff, C., S. Börner, S. Hacke, U. Kautzsch, D. Albrecht, H. M. Hammon, M. Röntgen, and B. Kuhla. 2012. Increased anaplerosis, TCA cycling, and oxidative phosphorylation in the liver of dairy cows with intensive body fat mobilization during early lactation. J. Proteome Res. 11:5503-5514. 